\title{
Semantic Prosody: Creating Awareness about a Versatile Tool
}

\author{
KAREN KORNING ZETHSEN \\ Institut for Sprog og Erhvervskommunikation, Handelshøjskolen, Århus, \\ Danmark
}

\begin{abstract}
Efter at korpuslingvistik er kommet ind i billedet, har leksikalsk semantik udviklet sig markant. I stedet for som tidligere at forlade sig på introspektion og illustrative eksempler kan nutidens semantiker, i mange tilfælde, få af- eller bekræftet sine hypoteser på baggrund af korpussøgninger. En af konsekvenserne af denne udvikling er, at man har fundet ud af, at leksikalsk betydning ikke så meget er et spørgsmål om betydning, der er isoleret i et leksem, men at der snarere er tale om såkaldte "extended units of meaning" (udvidede betydningsenheder) (Sinclair 1996) - i de fleste tilfælde er det umuligt at bruge et ord isoleret, uden at der følger mere med, da ords betydning påvirkes af de ord de oftest omgives af. Et direkte resultat af disse erkendelser er, at man er blevet bevidst om det semantisk/pragmatiske fænomen "semantisk prosodi" (Sinclair 1987, Louw 1993), en term der refererer til det faktum, at et ord ofte indeholder en negativ eller positiv vurdering afhængigt af, hvad det kollokerer med. Vel at mærke en vurdering, der i mange tilfælde er meget ubevidst og altså ikke tilgængelig via intuition, men som alligevel tydeligt kommer frem, når man sammenligner konkordanslinier. Det er denne artikels formål dels at undersøge fænomenet "semantisk prosodi" som et metodisk værktøj til at bestemme værdiladning i en tekst og dels at undersøge nogle af dets mange potentielle anvendelsesområder.
\end{abstract}




\section{INTRODUCTION}

Combinations of words in phrases are therefore a good candidate for the basic unit of language in use. (Stubbs 2001b: 14)

Within many linguistic areas we work with evaluation. Not necessarily in the sense that we assess the success or failure of a given text, but more to the effect that we analyse the evaluation ${ }^{1}$ (or expressivity/connotations/appraisal/stance, etc. - for a discussion of the terminology of evaluation see Hunston \& Thompson 2000: 2-6) which is expressed in a text as a means of finding out what is the message of a novel, the intended effect of a piece of persuasive writing, the hidden agenda of a political text, etc. Various techniques can be applied in the search for evaluative features in a text (see e.g. Hunston \& Thompson 2000: 13ff), but the concept of connotative meaning remains at the fore when explaining the nature of evaluative meaning (Stubbs 2001: 197, Hunston \& Thompson 2000: 2). And when it comes to connotative meaning or denotative meaning for that matter - the traditional unit of analysis is the lexeme. However, when carrying out semantic analyses I assume that many linguists have shared my experience of feeling the presence of a certain seme in e.g. a sentence, but have been unable to pin it to a lexeme and have consequently asked themselves whether a seme always arises from a lexeme, why not from another unit, a phrase, a sentence or from encyclopaedic knowledge?

In the first part of this article I will attempt to answer the following question: "Is individual word meaning a sound concept within semantic analysis?" I shall argue that it is not and as my focus will be on evaluative meaning I shall rely on the relatively recent concept of "semantic prosody" as an important part of my argumentation. In the second part of the article I intend to investigate and discuss the usefulness of the concept of semantic prosody to different branches of applied linguistics and associated trades.

\section{From leXeMe to "eXtended leXical UNits"}

Lexical semantics within the structuralist tradition entails independent word meaning which ideally can be finitely described by means of componential analysis (and denotation, not connotation is considered of main interest) - a rather static view which does of course not provide a satisfactory description of 
meaning in language use ${ }^{2}$. In fact it is highly doubtful whether a word is finitely describable at all. Many factors which are significant for the meaning of a word are idiosyncratic and strongly context-dependent. The structuralist tradition has given us many useful findings, but the limitations are evident once we move into the area of language use. If we take a Roschian view of meaning and apply the theory of prototypology ${ }^{3}$, context and encyclopaedic knowledge is taken into account. Instead of merely defining meaning as a question of sense relations within the language system, the theory of prototypology considers meaning a mental phenomenon which in addition to inherent lexical meaning helps us account for and describe connotative meaning. We can still for practical purposes work with semes, but instead of attempting an exhaustive analysis of a lexeme aim at a description of prototypical features, inherent or contextual. However, even if we reject the theory of meaning which believes in a finite description of the vocabulary, if we accept the existence of prototypes, if we include inherent as well as contextual aspects of meaning, the structuralist approach still implies that meaning is more or less isolated in the lexeme.

As early as 1934 Porzig made the very interesting observation that certain words co-occur. He pointed out the existence of "essential meaning relations" such as lick/tongue, blond/hair and bark/dog (see Lyons 1977: 261). Essential meaning relations are what Firth for the first time in 1957 calls "collocations" ("[...] I propose to bring forward as a technical term, meaning by 'collocation', 1957: 194). As is often pointed out (e.g. Lyons 1977: 612) Firth does not define collocability as precisely as one may wish, but one thing is clear; Firth rejects the Saussurean dualistic notion of signification:

\footnotetext{
Meaning by collocation is an abstraction at the syntagmatic level and is not directly concerned with the conceptual or idea approach to the meaning of words. One of the meanings of night is its collocability with dark, and of dark, of course, collocation with night. (Firth 1957: 196)
}

Firth was not always clear in his writings on collocation, so exactly what kind of importance he attached to the notion of collocation is a difficult question to answer. However, there is no doubt that Firth considered the tendency of lexemes to co-occur in texts an important part of their meaning. Firth died before the age of computers and corpus linguistics and therefore the pervasive nature of collocation in language in general was not observable to him - as we 
shall see below the extent of collocation even defies native-speaker introspection. Since the advent of computers and the subsequent development of corpus linguistics, important developments have been made within lexical semantics. Instead of mainly relying on introspection and a few illustrative examples the semanticist of today is in many cases able to obtain corpus evidence. One of the important consequences of these developments is the discovery that lexical meaning is not so much a question of meaning isolated in the lexeme, but rather in so-called "extended units of meaning" - a term introduced by Sinclair in 1996. John Sinclair, who was a student of Firth's has for decades been a central figure within corpus linguistics. Like Firth, Sinclair has a contextual/functional approach to meaning and corpora are used as evidence for new and revolutionary semantic insights (Stubbs 2001b: 22). Sinclair has for many years worked with collocational patterns and the importance of these patterns for the concept of meaning. Louw writes: "Sinclair's stated position has long been that the pursuit of independent word meaning has been as illusory as it has been sustained" (Louw 1993: 161). In an article from 1996, "The search for units of meaning" (Sinclair 1996), Sinclair develops a model which argues convincingly for the existence, or rather salience, of extended units of meaning (or compound lexical items as he also calls them). Sinclair puts forward the hypothesis that units of meaning are 'largely phrasal', that only a few words are selected independently of other words. The model consists of "four types of cooccurrence relations in extended lexico-semantic units" (Stubbs 2001b: 64 - see also Stubbs 2000a: 449), these four relations being collocation, colligation, semantic preference and semantic prosody (some of the below examples have been taken from Stubbs 2001b: 64ff which explains the model well):

\section{Collocation}

A frequent co-occurrence of word forms (physical evidence). Directly observable in textual data. Examples: rancid butter; thunderous applause; sustainable development.

\section{Colligation}

The co-occurrence of grammatical choices. Colligation is one step more abstract than collocation as it is the outcome of long sequences of analysis (structural evidence). Example: cases frequently co-occurs with the grammatical category of quantifier in some cases, in many cases. 


\section{Semantic preference}

A lexical set of frequently occurring collocates, which share a semantic feature, (i.e. not exactly the same words are involved, but rather words from the same lexical field). This concept is another stage removed from the actual words in the text - an abstract set is not directly observable, but the preferred lexis can be listed. Example: The adjective large is often followed by words from a group which could be called "quantities and sizes" such as number, scale, part, amounts. The verb commit is always followed by a noun phrase belonging to a semantic field which could be called "crimes and/or behaviour which is socially disapproved of" such as murder, adultery or sin (incidentally, this preference does also express a semantic prosody, which is the subject of the final, and evaluative, co-occurrence relation).

\section{Semantic prosody ${ }^{5}$}

Word forms which have a tendency to be (or in some cases which are always) followed by words with certain connotations, basically positive or negative (see below for further elaboration). Example: the verb cause is almost always followed by something negative such as problems, serious illness, death or damage. The verb provide is mostly followed by positive things such as service or support. By choosing a word form which in itself does not carry negative connotations but which has a negative semantic prosody the entire extended unit of meaning becomes attitudinal. According to Sinclair (1996: 87-88) a semantic prosody (or "discourse prosody" as Stubbs calls it) "shows how the rest of the item is to be interpreted functionally. Without it, the string of words just 'means' - it is not put to use in a viable communication". With semantic prosody we are close to the boundary of the lexical item and it can be discussed whether the phenomenon belongs within semantics or pragmatics (see Helle Dam-Jensen, Karen Korning Zethsen, in press, for a discussion of the boundary between semantics and pragmatics). One thing is clear though and very important for the aim of this article: "The initial choice of semantic prosody is the functional choice which links meaning to purpose". (Sinclair 1996: 88) [my emphasis]

Sinclair (1996: 94) concludes:

So strong are the co-occurrence tendencies of words [collocation], word classes [colligation], meanings [semantic preference] and attitudes [semantic prosody] that we must 
widen our horizons and expect the units of meaning to be much more extensive and varied than is seen in a single word.

When Sinclair talks about these extended units of meaning he does not mean the completely fixed expressions which we normally understand by collocations or idioms, but rather a fixed system, framework or matrix in which there is room for variation. In the case of colligation the framework may dictate that there has to be a preposition, but it can be one of many, with semantic preference a word with a certain seme may be required, but there may be many words to choose from, with semantic prosody there will be something attitudinal, but it may take many forms.

Stubbs (2001b: 63) concludes that Sinclair's model contains two closely related key ideas:

1. Meaning is typically dispersed over several word-forms which habitually co-occur in text.

2. These co-occurring word-forms 'share' semantic features.

In this article I shall lean on the work of Sinclair and Stubbs and maintain the position that meaning, and in particular evaluative meaning, cannot be limited to the lexeme. Meaning is rather a phrasal phenomenon and it makes more sense to work on the basis of extended units of meaning. Within a model of extended units of meaning it is at the level of semantic prosody that we find evaluation.

\section{SEMANTIC PROSODY}

One of Sinclair's main areas of interest is the description of vocabulary patterns and as early as in 1966 he noted that the word and the lexical item would not always coincide (Sinclair 1966). In 1987 Sinclair found computationally derived evidence for the existence of basically 'good/positive' or 'bad/negative' semantic profiles $^{6}$ or in other words whether a word form is likely to be followed by something basically positive or negative ${ }^{7}$ (Sinclair 1987). If we take the expression set in Sinclair found that in the majority of cases the subject of the expression was something negative, such as rot, decay, despair, bitterness, etc. and set in is thus described as having a bad semantic profile (see Sinclair 1987: 155- 
56). That is the most frequent collocates of set in gradually ${ }^{8}$ come to colour the expression itself so that taught by experience we come to expect something negative as a kind of default value when set in is uttered. In this way 'set in' cannot be seen in isolation - it cannot be semantically accounted for without including the influence of its most frequent co-texts ${ }^{9}$. This phenomenon was later named "semantic prosody"10 (Louw 1993: 157) (inspired by Firth's concept of phonological prosody) when Louw wrote his much cited article "Irony in the text or insincerity in the writer? The diagnostic potential of semantic prosodies" in 1993 (Louw 1993). Louw's article was directly based on Sinclair's 1987 work and he defines semantic prosody as "A consistent aura of meaning with which a form is imbued by its collocates" (Louw 1993: 157) or as Partington more precisely says further emphasising the phrasal element: "Semantic prosody refers to the spreading of connotational colouring beyond single word boundaries." (Sinclair 1996: 88).

Relevant for the focus of this article Sinclair provides a more abstract definition in 1996: "the functional choice which links meaning to purpose" (Sinclair 1996: 88), and in 2000 Hunston \& Thompson (2000: 38) (introduction to the article "Corpus-Based Analysis of Evaluative Lexis" by Joanna Channells) write:

\begin{abstract}
The notion of semantic prosody (or pragmatic meaning) is that a given word or phrase may occur most frequently in the context of other words or phrases which are predominantly positive or negative in their evaluative orientation ('polarity' is the term that Channell uses). As a result, the given word takes on an association with the positive or, more usually, the negative, and this association can be exploited by speakers to express evaluative meaning covertly. [my emphasis]
\end{abstract}

Louw (1993) has carried out several corpus analyses to corroborate Sinclair's evidence of the existence of semantic prosody. A well-known example from this article is Louw's analysis of utterly which he finds to have an overwhelmingly bad prosody with typical sentences such as The farmers were utterly against the union and In my experience it gets utterly confused (1993: 160). According to Louw (1993: 157) the phenomenon is largely inaccessible to human intuition and it cannot be retrieved reliably through introspection: "Semantic prosodies [...] are essentially a phenomenon that has been only revealed computationally, and 
whose extent and development can only be properly traced by computational methods".

The important discovery of the existence of semantic prosodies means that we cannot reveal connotative meaning in a text by simply looking at individual words. We must take into account the wider semantic/collocational patterns which these words form part of in order to reach the evaluations which are likely to be triggered in a reader's mind and for this we need computers and corpus studies. Semantic prosody is not a static phenomenon - it develops constantly (which is also why it is impossible to reach a finite description of the vocabulary) and may be difficult to pin down entirely, but it must be considered an indispensable tool for eliciting speaker attitude and making qualified guesses at likely hearer interpretation. The pioneering work of scholars such as Sinclair, Louw and Stubbs points in the direction of a phraseological approach to meaning and in particular to the concept of evaluation or speaker/hearer attitude. A phraseological approach provides valuable insights into the, often subtle, area of evaluation - insights which may be very useful within many linguistic and related areas.

\section{THE USEFULNESS OF SEMANTIC PROSODY AS A TOOL FOR ANALYSIS}

In the above I have discussed the theoretical implications of extended units of meaning versus the traditional focal point - the lexeme. Following Sinclair (1996) I have argued in favour of the more recent tendency which points towards a phraseological approach to meaning. An approach which furthermore questions the traditional semantics/pragmatics boundary: “[...] if attested examples of phraseological units are studied in large corpora, then this provides empirical evidence that pragmatic meanings are often conventionally encoded (in the text) rather than inferred (in the mind of the hearer/reader)" (Stubbs 2002: 438) ${ }^{11}$. When working with evaluation the phraseological approach entails that the concept of semantic prosody becomes of central interest. In the following I will discuss some of the linguistic areas which are likely to benefit from analyses based on semantic prosody. My aim is to exemplify various applications, not to provide exhaustive analyses within each area. The first and obvious area is that of lexicography. 


\section{Lexicography}

Traditionally dictionaries will of course include obvious, sometimes inherent, negative or positive values of a lexeme (in fact the inherent ones are not revealed through concordances). However, as we have seen good or bad prosodies are rarely accessible through introspection or the examination of a few real-life examples. What is needed is a large number of occurrences in order to be able to determine the semantic profiles of a given word and to include this important information in dictionaries.

\section{Example 2: Cause, set in and utterly}

Stubbs (1995 and 2001b) provides a classic example with the verb cause where he points out that the traditional definition make something happen should rather be make something bad happen as corpus searches show that cause has an overwhelmingly negative prosody. Other classic examples of words with strong negative prosodies are set in (Sinclair 1987: 155-56) and utterly (Louw 1993: 160).

According to the lexicographer Michael Hoey the practice of lexicography has undergone a revolution since the emergence of corpus linguistics (Hoey 1993: 1). Corpus-based dictionaries now include more advanced information on collocation, idioms, colligation and what he calls semantic association. Hoey does, however, not comment on the progress of semantic prosody specifically, but it goes without saying that the identification of semantic prosodies is very work-intensive. Some dictionaries do include prosodies, but as Partington (1998: 77) rather kindly suggests "there is still room for improvement". And according to Stubbs (2001b: 6) "[a] major finding of corpus semantics is that words and phrases convey evaluations more frequently than is recorded in many dictionaries". As regards bilingual dictionaries they cannot be said to be adapted to language use. "Language use" is of course not limited to semantic prosody, but as bilingual dictionaries often lack even widespread collocations, there is no doubt that good or bad prosodies are rarely included. Naturally, it goes for monolingual as well as for bilingual dictionaries that there are also practical limitations. Ideally, from a theoretical point of view, a large amount of information should be included for each entry, but to be useful in the real world it also requires the ability of the target users to digest this information. In spite of practical limitations an indication of a primarily good or bad semantic profile seems to be very desirable. 
It is not the aim of this article to evaluate specific dictionaries (see Partington 1998: 69-72 who discusses a number of dictionaries from the point of view of semantic prosody). Much is happening in the age of corpus-based lexicography, but even though some leading English-language dictionaries now include some information based on semantic prosody, the majority of dictionaries in use do not (for instance I cannot think of any Danish dictionaries that explicitly do).

The concept of semantic prosody is also potentially of great importance to 'evaluation in text':

\section{Text and discourse analysis}

When carrying out text analysis we often look for expressive or evaluative manifestations in the texts as the key to our interpretation of the text or what we perceive as the purpose of the author and the intended effect of the text on the reader. We use these analyses to interpret literature, to reveal the 'hidden persuaders' of advertising copy or political discourse, to elicit social or cultural norms, as the background for translation, etc.

\section{Critical discourse analysis}

Within the very broad area of critical discourse analysis the focus would not be on the pure semantic influence of good or bad prosodies, but rather the semantic profile of a given word could be used as the basis for investigating our perception/the status of objects or concepts in a social or political context, either generally speaking or within specific discourses.

\section{Example 3: Television/telly}

The lexicographer Michael Rundell gives a good example in Rundell (2000) with the words television/telly which he shows is so frequently surrounded (semantic preference) by a lazy/passive semantic class of verbs such as sprawled, plonked, curled up, lounge, installed and vegetate and overwhelmingly slumped that "[t]he word's downbeat flavour inevitably seeps through into the 'televisual' meaning. All of which looks like evidence for an institutionalized view of televisionwatching that perceives it as a mindless, passive activity engaged in by people who are too weak-willed, too witless or (at best) too exhausted to do anything else". 


\section{Example 4: Mobile phone}

In order to check this method I ran a simple concordance search on the British National Corpus on the word mobile phone. The query resulted in 50 random lines (out of 118 found). A quick look at the results revealed the following categories (I have not looked at their distribution, but have merely exemplified the categories I could find):

\section{Positive connotations}

The mobile phone is practical and provides security.

"The mobile phone has much to offer the family in practical, social and security terms."

"A mobile phone eliminates this problem and also means you are instantly contactable by your partner, childminder and children wherever you are."

\section{$\underline{\text { Negative connotations }}$}

The mobile phone is a nuisance. It never leaves you in peace, it takes time away from the family and is dangerous when driving.

"[...] a 40-year old wheeler-dealer American lawyer too busy with his mobile phone to turn up at his son's baseball games or take much heed of his daughter."

"I was carved up by a let-me-through Porsche, with a chap at the wheel chatting into his Deutsche Telekom mobile phone, and then caught up with the car again a few kilometres further on where it had slithered on the wet cobbles and collided with an antique tram."

\section{Neutral}

Dealing with e.g. technical matters.

"The mobile phone can be plugged into the cigar lighter socket of the hire car or, by means of a desk-top charger, be charged up via the mains."

In half an hour a quick search like the above may reveal very broad patterns of semantic preferences and perhaps prosodies which reflect the way we perceive an object or a concept. The results may show conflicting prototypical opinions, and in this way help the researcher form hypotheses and thereby provide a good vantage point for further discourse studies. 


\section{Example 5: Political discourse}

Within political discourse there is no doubt that analyses will be able to show how parties, newspapers, etc., for ideological reasons choose to use various key words which they surround with a semantic universe which comes to influence our perception of these key words or concepts. It is not that the core meaning of these words is changed, but it is rather a case of the words taking on new context-dependent connotations defined by their typical collocations in certain kinds of discourse. In Fairclough's "New Labour, New Language?" (2000) the entire book is built around the analysis of such key words on the basis of corpus searches. By analysing the concordance lines of key words in New Labour rhetoric, such as values, rights and responsibilities, duties, poverty, partnership, reform and fairness Fairclough demonstrates how these concepts can be said to have developed a New Labour meaning/interpretation as the result of their typical New Labour contexts. Fairclough's claim is that, over time, Labour has been successful in designing some of the connotations of their chosen key words.

Also Partington (1998: 76) reflects along these lines in relation to political discourse:

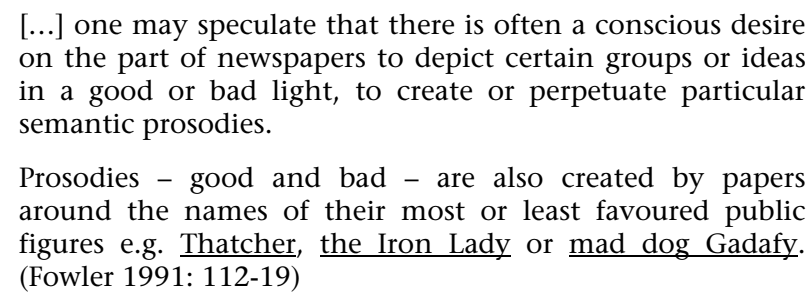

and points out that an awareness of semantic prosodies can be extremely useful for native and non-native alike in uncovering a text producer's hidden attitudes (Partington 1998: 8).

\section{Text production}

\section{Persuasive writing}

As a linguist it is natural to look at a phenomenon from a critical point of view as is the case with critical discourse analysis. However, it follows from the above that semantic prosody will also be of interest to those professionally engaged in 
persuasive writing (persuasive writing should be interpreted broadly as most communicators frequently make use of persuasive language even though they are not "professional persuaders" so to speak). In the conclusion of his famous article Louw (1993: 1973) writes: "It is plain that semantic prosodies will be of great assistance in the persuasion industry. Propaganda, advertising and promotional copy will now be gradable against the semantic prosodies of the whole language [...]". Tognini Bonelli (2001: 113) furthermore points out that companies spend large amounts of money to make sure that their brand names and slogans carry only positive and relevant overtones.

\section{Example 6: Kvalitetstid 'quality time'}

On the front page of a Danish package tour catalogue by one of the main operators in the field the word kvalitetstid 'quality time' was used to indicate one of the positive features of a family package holiday. Intuitively I reacted against the use of the word, because to me it is a buzzword of the 1980s and 1990s which has become loaded with connotations of guilt-ridden full-time working parents who try to make up for their lack of time with their offspring and therefore call the little time they actually spend together "quality time". That is, to me personally it is not a positive word and I suspected that the word might have developed negative connotations. I therefore ran a corpus search on Korpus $2000^{12}$. Sixteen examples were found and from their context it was possible to decide that 8 examples were using the word in a positive sense and 8 examples were using the word in a negative, ironic sense, i.e. a fifty-fifty situation. The following sentences illustrate each category:

\section{$\underline{\text { Positive connotations }}$}

Seerne følger tre småbørnsfamilier, der er villige til at loegge deres liv fuldstoendig om for at få mere kvalitetstid med børnene.

'The viewers follow three families with small children who are willing to change their lives completely in order to get more quality time with the children.'

Mange mennesker har i virkeligheden ret enkle visioner. De handler typisk om at kunne få lidt mere fritid, lidt mere kvalitetstid med børn og familie [...]

'In reality many people have quite simple visions. Typically to get a little more spare time, a little more quality time with children and family [...]' 


\section{Negative connotations}

Vi tror, at vi kan styre alting - at vi kan gøre hvad der passer os. Vi lever i en tidsalder og en verden, hvor man taler om kvalitetstid. Det begreb holder ikke.

'We believe we can control everything - that we can do just what we want. We live in a time and age where the expression quality time is used. This concept does not hold water.'

Når det drejer sig om børnene taler vi om kvalitetstid for at skjule, at vi ikke har tid til at tilbringe ret meget tid sammen med dem.

'When we talk about the children we use the expression quality time to hide the fact that we do not have time to spend very much time with them.'

A likely hypothesis would be that kvalitetstid started life as a fairly positive concept to many people, but through time it has picked up negative connotations from the increased criticism of the way of life it entails and its verbal manifestations.

In the immediate surroundings of the expression we find each of the following words several times (with slight variations in the actual expressions):

- $\quad$ stresset hverdag, fortravlede foroeldre 'stressful life', 'too busy parents'

- fuldtidsjob 'full-time job'

- $\quad$ karriere 'career'

- daginstitution 'day-care centre'

- dårlig samvittighed 'bad conscience'

together with single occurrences of words like:

- $\quad$ myte 'myth'

- $\quad$ ulvetime 'literally 'wolf hour'. Danish word for the hour in late afternoon when the exhausted family arrives home and has to start cooking dinner'

- $\quad$ foerdigretter 'ready-prepared meals'

These words and expressions give a very clear picture of the problem involved and it is important to note that although they are more frequent with the negative occurrences of kvalitetstid they are not limited to these. Many of the positive occurrences are concerned with the lack of kvalitetestid. It seems reasonable to conclude that the negative surroundings, linguistically as well as 
extra-linguistically have influenced the connotations of the expression. The above illustrates why it could be time well spent for an advertising agency to have a linguist run a corpus search and interpret the results of e.g. campaign key words. It should be added that a word like kvalitetestid which has an equal distribution of negative and positive occurrences is of course more likely to be interpreted in either way in different discourse communities. ${ }^{13}$ However, in the case of a package holiday catalogue primarily aimed at all Danish families with children it may not be the best word to choose.

\section{Translation}

Within translation studies the usefulness of e.g. large parallel corpora has been acknowledged for at least a decade. Translation-relevant corpus-based research is quickly gaining momentum as witnessed by a great number of publications on the subject and events such as the large conference, "Corpus-based Translation Studies Research and Applications", held in Pretoria in the summer of 2003. ${ }^{14}$ As regards the specific subject of semantic prosody it is bound with time to influence our perception of the concept of equivalence (see e.g. Ruta Marcinkeviciene 1998). A likely hypothesis is that the traditional problem of "false friends" within translation is much more pervasive than assumed up till now. Presumably equivalent words may have developed differently in two languages and have during time been influenced by the company they have kept and thereby developed different prosodies. Partington (1998: 77) indicates that his own research shows that "look-alike words from two related languages can have very different semantic prosodies") and he concludes: "The pitfalls for translators unaware of such prosodic differences are evident." (ibid: 78). Also, the concept of extended lexical units on which semantic prosody builds is important for the translator to be aware of as it shifts undue focus on individual lexemes as the unit of translation to larger (and more meaningful) units of meaning.

For the practicing translator, being able to interpret evaluation in a source text and the semantic profiles of translation choices in the target language is of utmost importance. As research on semantic prosody has shown and as discussed above in the section on lexicography the connotations acquired in repeated contexts, i.e. semantic prosody, are far from always recorded in monolingual dictionaries and almost never in bilingual ones which means that 
the translator often does not have access to information on the semantic profiles of words. Time is of the essence to the professional translator and it goes without saying that it is rarely possible to carry out individual queries and analyses. In other words translators will undoubtedly welcome lexicographical developments within the field of semantic prosody.

\section{Example 7: Impresionante/impressive/imponerende}

Partington (1998) provides a good example with the Italian/English pair of seemingly similar words impresionante/impressive. The English adjective impressive typically collocates with words such as achievement, talent and dignity and can therefore be said to have a positive profile whereas its Italian look-alike impresionante often collocates with neutral or negative terms such as series of price rises and assassination attempts giving it a somewhat unfavourable bias. A search in Korpus 2000 (accessed June 2005 - 778 examples found) shows that the Danish corresponding adjective imponerende like impressive has an overwhelmingly positive semantic profile the most frequent collocates being samling 'collection', resultater 'results', karriere 'career', evne 'ability/talent', prostation 'achievement' and opbud 'turnout'.

\section{Foreign language teaching}

It is fairly evident that the concept of semantic prosody is relevant for foreign language teaching as well, as witnessed by the above examples from lexicography, critical discourse analysis, persuasive writing and translation, especially when learners reach an advanced level where grammatical correctness is no longer a problem:

\footnotetext{
Collocations and idioms are of the greatest importance to the language learner; one of the things that distinguishes an advanced learner's language from that of a native speaker is that advanced learners often manifest grammatical correctness but collocational inappropriateness. (Hoey 2003: 3)
}

The student must first and foremost be made conscious of the phenomenon of semantic prosody and of the concept of extended lexical units which it entails. The foreign language students of today are tomorrow's translators and copy writers and they constantly run the risk of triggering the wrong/unfortunate connotations in the foreign language texts they produce and as far as the 
translators are concerned there is the additional risk of misinterpreting the more subtle evaluative meaning of the source text which is often closely linked with the communicative purpose. Partington (1998: 72) points out that information on prosody is particularly important for non-native speakers as they are more vulnerable to the hidden intentions of the text producer than native speakers, who probably have some sensitivity to it at a subconscious level.

For the foreign language teacher/student access to the semantic prosodies of words relies quite heavily on the inclusion of such information in dictionaries and other reference works, but also on the teacher's ability to train learners "to get the best out of the cornucopia of information contained in a corpus-based dictionary." (Hoey 2003: 8). Hoey points out that a new generation of dictionaries requires a new generation of learners to use them.

\section{CONCLUSION}

The list of possible applications of the tool of semantic prosody seems almost endless. Also within genre theory or literary studies, to mention a few, it would be insightful to study the prosodies of words or expressions used within a certain genre or by a certain author (as when Firth talks about "Swinburnian patterns of collocation", 1957: 197) where this insight could assist in the interpretation of the text. Within most professions time is of the essence which is why access to prosodies should ideally be provided by advanced corpus-based dictionaries and what is more, the phenomenon of semantic prosody, and the fact that meaning is not so much centred in individual lexemes as it is the product of extended lexical units, should be taught at institutions offering advanced studies in linguistics, foreign languages, translation or communication. More widespread awareness of the (relatively recent) concept and the key it offers to the nature and interpretation of meaning is needed. In the larger picture a more phraseological approach to lexical semantics may well prove very useful.

\section{REFERENCES}

Dam-Jensen, Helle, Karen Korning Zethsen, "Pragmatic patterns and the lexical system - a reassessment of evaluation in language", in press, Journal of Pragmatics.

Fairclough, Norman (2000), New Labour, New Language, London: Routledge.

Firth, John Rupert (1957), Papers in Linguistics 1934-1951, London: Oxford University Press. 
Hoey, Michael (2003), “What's in a word?", in: MED Magazine, http://www.macmillandictionary.com/MED-Magazine/August2003/10Feature-Whats-in-a-word.htm, Issue 10, August 2003, First published in English Teaching Professional issue 27, April 2003.

Hunston, Susan, Geoff Thompson (1999), Evaluation in Text, Oxford: Oxford University Press.

Louw, Bill (1993), "Irony in the text or insincerity in the writer? - the diagnostic potential of semantic prosodies", in: Baker, M., G. Francis, E. Tognini-Bonelli (eds.) (1993), Text and Technology, Amsterdam: John Benjamins Publishing Company, pp. 157-176.

Lyons, John (1977), Semantics, 2 vols., Cambridge: Cambridge University Press.

Marcinkeviciene, Ruta (1998), "Parallel corpora and bilingual lexicography", in: Usoniene, A. (ed.) (1998), Germanic and Baltic Linguistic Studies and Translation, Proceedings of the International Conference, 22-24 April 1998, Vilnius, pp. 40-48.

Munday, Jeremy, "Looming large: A cross-linguistic analysis of semantic prosodies in comparable reference corpora", submitted for publication in the proceedings of the Corpus-Based Translation conference in Pretoria, South Africa, July 2003 http://www.surrey.ac.uk/lcts/cts/staff/munday.htm

Partington, Alan (2004), "Utterly content in each other's company: Semantic prosody and semantic preference", International Journal of Corpus Linguistics, 9/1 (2004), pp. 131-156.

Partington, Alan (1998), Patterns and Meanings. Using corpora for English language research and teaching, Amsterdam: John Benjamins Publishing Company.

Porzig, Walter (1934), "Wesenhafte Bedeutungsbeziehungen", in: Beiträge zur deutschen Sprache und Literatur, 58 (1934), pp. 70-97.

Rosch, Eleanor (1973), "On the internal structure of perceptual and semantic categories", in: Moore, T. E. (ed.) (1973), Cognitive Development and the Acquisition of Language, New York: Academic Press, pp. 114-144.

Rundell, Mike (2000), "Slumped in front of the telly", in: Humanising Language Teaching, 1 (2000), http://www.hltmag.co.uk/jan00/idea.htm

Sinclair, John (1966), "Beginning the study of lexis", in: Bazell, C. E., J. C. Catford, M. A. K. Halliday, R. H. Robins (eds.) (1996), In Memory of J. R. Firth, London: Longman, pp. 410-430.

Sinclair, John (ed.) (1987), Looking Up. An Account of the COBUILD Project in Lexical Computing, London/Glasgow: Collins.

Sinclair, John (1996), "The search for units of meaning", in: Textus: English Studies in Italy, 9 (1996), pp. 75-106.

Stubbs, Michael (1995), "Collocations and semantic profiles: on the cause of the trouble with quantitative studies", in: Functions of Language, 2/1 (2001), pp. 23-55.

Stubbs, Michael (2001a), "On inference theories and code theories: corpus evidence for semantic schemas", in: Text, 21/3 (2001), pp. 436-465. 
Stubbs, Michael (2001b), Words and Phrases. Corpus Studies of Lexical Semantics, Oxford: Blackwell.

Tognini-Bonelli, Elena (2001), Corpus Linguistics at Work, Amsterdam: John Benjamins.

\section{CORPORA}

British National Corpus http://sara.natcorp.ox.ac.uk/lookup.html

Korpus 2000 http://korpus.dsl.dk/korpus2000/indgang.php

\section{NOTES}

1 In this article Hunston \& Thompson's (2000: 5) definition of 'evaluation' is applied: "[...] evaluation is the broad cover term for the expression of the speaker or writer's attitude or stance towards, viewpoint on, or feelings about the entities or propositions that he or she is talking about. That attitude may relate to certainty or obligation or desirability or any of a number of other sets of values."

2 Though componential analysis and the notion of semantic features - or semes - as tools for the description of meaning - instead of as a general theory of meaning - are very useful.

3 According to Rosch (1973) human beings categorise by means of prototypes, i.e. many categories are mentally represented by means of schemata of their most characteristic members. Other members constitute borderline cases and are peripheral in nature. Put in another way our linguistic categories have a hard core and blurred or fuzzy edges.

4 In Stubbs (2001a) 'colligation' is listed before 'semantic preference' and vice versa in Stubbs (2001b).

5 The distinction between semantic preference and semantic prosody is not entirely clear-cut and the problem is linked to the semantics/pragmatics question - for a detailed discussion see Partington (2004).

6 Louw 1993 also uses the expression 'prosodic profile', but interchangeably with 'semantic profile'. It seems that both expressions stand for the results of a corpus search. I.e. whether a lexeme or a text sequence has a good or a bad profile.

7 That is basically negative/positive, but a more refined categorisation of semantic profiles can of course be made with headings such as "difficulty", "reluctance" "uncertainty" or "desirable", "necessary".

8 "Prosodies are undoubtedly the product of a long period of refinement through historical change [...]" (Louw 1993: 164). Consequently, there must be strong and less strong prosodies as well as prosodies under development.

9 Also, if we take two consecutive words in a text - which would not normally be described as a collocation - instead of just one lexeme we may find semantic prosodies as well (see Louw 1993 and his example with days are)

10 According to Louw the term 'semantic prosody' was first cornered by Sinclair in 1988 (personal communication between Louw and Sinclair), but Tognini-Bonelli attributes the term to Louw himself. Anyway, Louw (1993) was the first time the term was seen in print.

11 See also forthcoming Dam-Jensen and Zethsen in press for a discussion on the semantics/pragmatics boundary. 
12 For the analyses I have made use of a fairly new Danish corpus - Korpus 2000. It is a corpus of about 28 million words the aim of which is to document the use of the Danish language around the year 2000, or rather the use of written Danish as no speech is included. The texts on which the corpus is based have been written between 1998 and 2002 and come from all conceivable areas. Korpus 2000 was made accessible in 2002 and is the result of work carried out by DSL - a Danish language and literature society under the auspices of the Danish Ministry of Culture. The concordance lines were retrieved in June 2005.

13 As Partington (1998: 17) points out "[c]ollocational normality is dependent on genre, register and style, i.e. what is normal in one kind of text may be quite unusual in another."

14 See e.g. Jeremy Munday's article "Looming large: A cross-linguistic analysis of semantic prosodies in comparable reference corpora" http://www.surrey.ac.uk/lcts/cts/staff/ munday.htm (submitted for publication) 